\title{
INTERNET ADDICTION AND QUALITY OF LIFE OF ADOLESCENTS WHO APPLY TO FAMILY MEDICINE OUTPATIENT CLINICS DURING THE COVID-19 PANDEMIC PROCESS
}

\author{
Ece Ezgi ÖZAYKAN ${ }^{1}$, Emin PALA ${ }^{1 *}$, Süleyman ERSOY1 \\ ${ }^{1}$ University of Health Sciences Turkey, Hamidiye Faculty of Medicine, Umraniye Training and Research Hospital, Department of Family \\ Medicine, 34668, İstanbul, Turkey
}

\begin{abstract}
The aim of the study was to evaluate the internet addiction and quality of life of adolescents admitted to family medicine outpatient clinics and to examine the relationship between this situation and the pandemic process. This cross-sectional study included 126 adolescent who applied to Family Medicine Polyclinics between July 10 and September 10, 2020. A socio demographic questionnaire, young internet addiction scale (YIAT-SF), World Health Organization Quality of Life Short form, Turkish Version (WHOQOL-BREF-TR) were applied to determine the level of internet addiction and quality of life by calculation of total score. $50 \%$ of the adolescents in our study were females and $50 \%$ were males. The mean age was 13.2 years \pm 3.2 years (median: 13 years) and 82 of the children (65.08\%) were attending primary school-secondary school, and $44(34.92 \%)$ were attending high school. In the survey, it was seen that they had less social friendship and playing on the street as their social environment are based on social media. It was seen that $87 \%$ of the adolescents who participated in the survey had internet connection at home. The use of social media during the pandemic process increased and even adolescents who did not post anything in the social media before the pandemic process shared their posts more frequently. During the pandemic process, sleep disturbances, increased daily sleep hours and weight gain was observed. In the Covid-19 period an increase in internet addiction and a decrease in the quality of life were seen in adolescents.
\end{abstract}

Keywords: Covid-19, Internet addiction, Adolescent, Quality of life

*Corresponding author: University of Health Sciences Turkey, Hamidiye Faculty of Medicine, Umraniye Training and Research Hospital, Department of Family Medicine, 34668, İstanbul, Turkey

E mail: eminpala72@gmail.com (E. PALA)

Ece Ezgi ÖZAYKAN (D) https://orcid.org/0000-0002-4842-8984

Emin PALA (iD) https://orcid.org/0000-0001-9189-4342

Süleyman ERSOY (iD) https://orcid.org/0000-0003-0001-9329

Received: March 16, 2021

Accepted: April 20, 2021

Published: September 01, 2021

Cite as: Özaykan EE, Pala E, Ersoy S. 2021. Internet addiction and quality of life of adolescents who apply to family medicine outpatient clinics during the covid-19 pandemic process. BSJ Health Sci, 4(3): 282-288.

\section{Introduction}

Covid-19 originating from Wuhan, China has spread worldwide and called as a pandemic by World Health Organization. This pandemic had tremendous impact worldwide both economically and socially.

The COVID-19 is an extremely contagious disease with high infectivity, fast transmitting speed, and susceptibility of all-age groups, and damage to public health (Dong et al., 2020). Isolation is among the principal preventive measures during the pandemic. States had to curb freedom of the people due to the pandemic. In the meantime social life is encountered with many significant alterations (Banerjee, 2020).

Covid-19 pandemic damaged global economy excessively. Travel restrictions and isolation measures kept people away from social interaction milieu such as cafes, restaurants and movie theatres and force them to stay and spend their life at home (Banerjee., 2020). As researchers all over toil hard for an effective anti-viral and vaccine against COVID-19, the psychological impact of the illness is largely neglected. Pandemics like this, are not just a medical phenomenon; they tend to affect quality of life in an individual and as a whole, causing social dysfunction (Banerjee, 2020).

Internet addiction (IA) among adolescents is a serious public health problem around the world. Electronic devices such as television, computers, mobile phone and tablet PC become the main element of social life and led to IA in school children who get online education from home and kept away from social interaction (Suryaman et al., 2020). In our study we aimed to assess impact of Covid-19 era on internet addiction and quality of life of adolescents.

\section{Material and Methods}

\subsection{Population and Sample}

The study was conducted in İstanbul Umraniye Training and Research Hospital Family Medicine Outpatient unit between August 15 - October 15 - 2020 on adolescents which was defined by WHO as the phase of life between childhood and adulthood, from ages 10 to 19 (WHO, 2021). Inclusion criteria were being 10 to 19 years old, 
giving consent to participation. The adolescents who were diagnosed with mental disorders are excluded Since the precise population is not known sample calculation couldn't be done.

\subsection{Research Method}

In this study impact of Covid-19 era on internet addiction and quality of life of adolescents is assessed. This is a cross-sectional correlation -seeking study. This model allows investigation of the frequency of the parameters of interest within the whole population and allows researchers to collect data that can be generalized to the whole population (Metintas et al., 2019).

\subsection{Methods of Data Acquisition}

A questionnaire consisting from 32 item multiple-choice questions to obtain sociodemographic data, young internet addiction scale (YIAT-SF) consisting from 12 questions to assess internet addiction and Turkish version of WHO Quality of Life Scale Short Form were applied to the participants with face to face interview method and based on total score internet addiction and level of quality of life were scored. Scales used in the study were 5-point Likert type.

In young internet addiction scale (YIAT-SF), the score is between 12- to 60-points. There is no counter item in the test. Higher scores indicate more addiction to internet (Pawlikowski et al., 2013). Kutlu and colleagues translated the scale into Turkish and conducted validity and reliability studies for the scale (Kutlu et al., 2016). WHO Quality of Life Short Form (WHOQOL-BREF) is the short form of a 100-items questionnaire called WHOQOL100 , which has been developed by WHO and measures quality of life. Each question is between 4- to 20-points. Higher scores indicate better quality of life (WHOQoL Group, 1994). It consists of four main domains as physical and psychological wellbeing, social relationships and environment. It also includes a division to assess overall health and quality of life. While the latter includes only two questions, the remaining 24 questions are related to each of the domains mentioned above. The score of each domain was calculated by summing the points which can be 1 to 5 according to the answer to each question. WHOQOL-BREF-TR 27 is consisted of 27 questions. It was developed by Eser and colleagues in 1999 adding one more question while the validity and reliability studies of the 26-items form in Turkish subjects (Eser et al., 1999).

The questionnaire that is used for the survey is formulated by consulting to child psychiatry specialists and public health specialists, by studying other awareness tests in the literature, by considering conformity of it to ethnic and traditional traits of Turkish population which is the target population and by paying attention to use an understandable language. For reliability of the questionnaire and to get clear results survey is carried out by face to face interview rather than online test or testing via e-mail.

\subsection{Statistical Analysis}

SPSS 25.0 package program was used for statistical analysis. While evaluating the study data, the distribution of the data was tested using the descriptive statistical method (Mean, Standard Deviation, Frequency) as well as the Shapiro-Wilk test. For the quantitative data with normal distribution, one of the parametric tests, the Independent $t$ test was used. Pearson's correlation analysis was used to evaluate the relationships between quantitative variables. The level of significance was evaluated at the $\mathrm{P}<0.05$ level.

\section{Results}

Out of 126 adolescents participated in the study $50 \%$ was female and $50 \%$ was male. Mean age of the patients is 13.2 years \pm 3.2 (median=13) and $82(65.08) \%$ of them are attending to primary/secondary school and 44 $(34.82 \%)$ are attending to high school. Family income is below 5000 TL in $59 \%$ of the participants (Table1).

Table 1. Demographic characteristics of adolescents participating in the survey

\begin{tabular}{lccc}
\hline Category & Variable & $\mathrm{n}$ & $\%$ \\
\hline Sex & Male & 63 & 50 \\
& Female & 63 & 50 \\
Education level of & Primary/secondary & 82 & 65 \\
Adolescent & school & & \\
Income level of the & High school & 44 & 35 \\
family & Below 5.000 TL & 74 & 59 \\
\hline
\end{tabular}

$87 \%$ of the participants had internet access at home and one of every 2 adolescents had at least two social media account. Participants gave the highest score to the question, "How often your school or homework studies are negatively affected by the time you spend in the internet?" Participants gave the lowest score to the question, "How often do you try to conceal how long you stayed while surfing in the internet?" (Table 2).

Definition of social circle differs between adolescents according to their internet addiction level $(\mathrm{P}=0.029)$. Internet addiction is higher in those who describe social circle as social media rather than friendship. And internet addiction is higher in adolescents who have internet access at home. $(\mathrm{P}<0.001)$ And internet addiction is higher in adolescents who have parents graduated from high school compared to junior college or university $(\mathrm{P}=0.034)$ (Table3). 
Table 2. Internet addiction level of adolescents participating in the survey

\begin{tabular}{lc}
\hline Question & Average \\
\hline How often do you surf in the internet more than you planned to? & 3.00 \\
How often do you spend time in internet, while neglecting your duties related with the family? & 3.21 \\
How often your school or homework studies are negatively affected by the time you spend in the & 3.43 \\
internet? & 2.86 \\
When someone asks you what you are doing during internet surfing, how often do you conceal it or & \\
behave in a defensive manner? & 2.79 \\
If someone bothers you while you are surfing in the internet, how often do you rebuff them, yell at them \\
or behave in anger? & 3.14 \\
How often are you deprived of sleep since you spend your night while surfing in the internet? & 3.07 \\
How often do you console yourself by thinking about surfing in the internet or dream about it while you \\
aren't connected to internet? & 2.93 \\
How often do you find yourself saying "just a few minutes more"? & 3.07 \\
How often do you try to shorten the time you spend in internet but fail? & 2.64 \\
How often do you try to conceal how long you stayed while surfing in the internet? & 3.00 \\
How often do you prefer to spend your time in the internet instead of going out with some friends? & 3.14 \\
While you are not connected to internet how often do you feel yourself depressed, pessimistic or nervous & \\
and see all is gone immediately after you connected to internet?
\end{tabular}

Table 3. Internet addiction level of adolescents according to demographic characteristics

\begin{tabular}{|c|c|c|c|c|c|c|c|}
\hline Dimension & Group & $\mathrm{N}$ & Mean & $\begin{array}{l}\text { Standard } \\
\text { Deviation }\end{array}$ & $\mathrm{t}$ & sd & $P$ \\
\hline \multirow{2}{*}{ Sex } & Female & 63 & 3.0093 & 0.4887 & \multirow{2}{*}{-0.356} & \multirow{2}{*}{124} & \multirow{2}{*}{0.723} \\
\hline & Male & 63 & 3.0384 & 0.426 & & & \\
\hline \multirow[t]{2}{*}{$\begin{array}{l}\text { Education level of } \\
\text { Adolescent }\end{array}$} & $\begin{array}{l}\text { Primary } \\
\text { /secondary } \\
\text { school }\end{array}$ & 82 & 3.0071 & 0.4758 & \multirow[t]{2}{*}{-0.558} & \multirow[t]{2}{*}{124} & \multirow[t]{2}{*}{0.578} \\
\hline & High school & 44 & 3.0549 & 0.4253 & & & \\
\hline \multirow[b]{2}{*}{$\begin{array}{l}\text { Residence of the } \\
\text { Adolescents }\end{array}$} & With family & 113 & 3.0236 & 0.4580 & \multirow[b]{2}{*}{-0.015} & \multirow[b]{2}{*}{124} & \multirow[b]{2}{*}{0.988} \\
\hline & $\begin{array}{l}\text { Boarding or } \\
\text { staying with } \\
\text { relatives }\end{array}$ & 13 & 3.0256 & 0.4731 & & & \\
\hline \multirow{2}{*}{$\begin{array}{l}\text { Social environment } \\
\text { definition of the } \\
\text { adolescents }\end{array}$} & Social Media & 63 & 3.1124 & 0.4379 & \multirow[b]{2}{*}{-2.207} & \multirow[b]{2}{*}{124} & \multirow[b]{2}{*}{0.029} \\
\hline & Friends & 63 & 2.9352 & 0.4631 & & & \\
\hline \multirow{2}{*}{$\begin{array}{l}\text { Internet connection } \\
\text { at home }\end{array}$} & Yes & 109 & 3.5392 & 0.0429 & \multirow{2}{*}{-5.557} & \multirow{2}{*}{124} & \multirow{2}{*}{0.000} \\
\hline & No & 17 & 2.9434 & 0.4402 & & & \\
\hline \multirow{2}{*}{$\begin{array}{l}\text { Education level of } \\
\text { the family }\end{array}$} & High school & 82 & 3.078 & 0.4447 & \multirow[b]{2}{*}{2.142} & \multirow[b]{2}{*}{124} & \multirow[b]{2}{*}{0.034} \\
\hline & $\begin{array}{c}\text { Junior college or } \\
\text { university }\end{array}$ & 44 & 2.9323 & 0.4384 & & & \\
\hline \multirow{2}{*}{ Family income } & Below $5.000 \mathrm{TL}$ & 74 & 3.0186 & 0.4398 & \multirow{2}{*}{-0.372} & \multirow{2}{*}{124} & \multirow{2}{*}{0.710} \\
\hline & Over 5.000 TL & 52 & 3.0433 & 0.4594 & & & \\
\hline
\end{tabular}

\subsection{Participants' Quality of Life during Pandemic}

The question about pandemic, "how do you find online education given during pandemic?" is responded as "poor" by $96 \%$ of the adolescents.

It's observed that due pandemic irregular sleep patterns and hours of sleep during daylight have increased in participants (97\%) and also in $83 \%$ of them weight gain has occurred due to irregular sleep.

When adolescents were questioned about their relations with family members during pandemic, regardless of income level $90 \%$ of the participants have said there were "negative" changes. They have run to street as soon as the normalization period started.

Another impact of pandemic is change in "reading habit". The question "How many books were you reading before pandemic?" and "was there a change in the number of books you read during pandemic?" were responded by no change in $50 \%$ of the participants and total evasion 
from book reading in the other $50 \%$. The highest score in quality of life of adolescents was achieved in environment domain and the lowest score was obtained in social domain. In other words, during pandemic life quality decreased the most in social domain. (Table 4). Quality of life scores didn't differ regarding residence place of adolescents, education status, and income level of the family and definition of social circle. Analysis has revealed higher quality of life scores for females compared to males ( $\mathrm{P}=0.049)$ (Table 5).
Table 4. Life quality scores of the adolescents participating in the survey

\begin{tabular}{ll}
\hline Domain & Quality score \\
\hline Physical health & $13.74 \pm 3.18$ \\
Psychological health & $13.56 \pm 2.49$ \\
Social interactions & $13.33 \pm 3.10$ \\
Environment & $14.51 \pm 2.22$ \\
\hline
\end{tabular}

Table 5. Life quality scores of the adolescents according to demographic characteristics

\begin{tabular}{|c|c|c|c|c|c|c|c|}
\hline Dimension & Group & $\mathrm{N}$ & Mean & $\begin{array}{l}\text { Standard } \\
\text { Deviation }\end{array}$ & $\mathrm{t}$ & sd & $\mathrm{P}$ \\
\hline \multirow{2}{*}{ Sex } & Female & 63 & 2.8926 & 0.3598 & \multirow{2}{*}{2.051} & \multirow{2}{*}{124} & \multirow{2}{*}{0.049} \\
\hline & Male & 63 & 2.7833 & 0.3379 & & & \\
\hline \multirow{2}{*}{$\begin{array}{l}\text { Education level of } \\
\text { Adolescent }\end{array}$} & $\begin{array}{l}\text { Primary/secondary } \\
\text { school }\end{array}$ & 82 & 2.8438 & 0.3490 & \multirow[t]{2}{*}{0.255} & \multirow[t]{2}{*}{124} & \multirow[t]{2}{*}{0.799} \\
\hline & High school & 44 & 2.8269 & 0.3628 & & & \\
\hline \multirow{2}{*}{$\begin{array}{l}\text { Residence of the } \\
\text { Adolescents }\end{array}$} & With family & 113 & 2.8319 & 0.3493 & \multirow[b]{2}{*}{-0.567} & \multirow[b]{2}{*}{124} & \multirow[b]{2}{*}{0.572} \\
\hline & $\begin{array}{c}\text { Boarding or staying } \\
\text { with relatives }\end{array}$ & 13 & 2.8905 & 0.3903 & & & \\
\hline \multirow{2}{*}{$\begin{array}{l}\text { Social environment } \\
\text { definition of the } \\
\text { adolescents }\end{array}$} & Social Media & 63 & 2.8242 & 0.3747 & \multirow[t]{2}{*}{-0.436} & \multirow[t]{2}{*}{124} & \multirow[t]{2}{*}{0.664} \\
\hline & Friends & 63 & 2.8516 & 0.3314 & & & \\
\hline \multirow{2}{*}{$\begin{array}{l}\text { Internet connection at } \\
\text { home }\end{array}$} & Yes & 109 & 2.7919 & 0.3616 & \multirow{2}{*}{0.578} & \multirow{2}{*}{124} & \multirow{2}{*}{0.053} \\
\hline & No & 17 & 2.8451 & 0.3523 & & & \\
\hline \multirow{2}{*}{$\begin{array}{l}\text { Education level of the } \\
\text { family }\end{array}$} & High school & 82 & 2.8332 & 0.3524 & \multirow[b]{2}{*}{0.746} & \multirow[b]{2}{*}{124} & \multirow[b]{2}{*}{0.457} \\
\hline & $\begin{array}{l}\text { Junior college or } \\
\text { university }\end{array}$ & 44 & 2.7933 & 0.341 & & & \\
\hline \multirow{2}{*}{ Family income } & Below $5.000 \mathrm{TL}$ & 74 & 2.8235 & 0.3583 & \multirow{2}{*}{0.18} & \multirow{2}{*}{124} & \multirow{2}{*}{0.857} \\
\hline & Over $5.000 \mathrm{TL}$ & 52 & 2.8142 & 0.3352 & & & \\
\hline
\end{tabular}

\subsection{Internet addiction and quality of life correlation} in participants during pandemic

Internet addiction of the participants isn't statistically significantly correlated with general health status subdomain $(\mathrm{P}=0.156)$, physical health subdomain $(\mathrm{P}=0.905)$, psychological health subdomain $(\mathrm{P}=0.430)$, environment subdomain $(\mathrm{P}=0.738)$ and social engagement subdomain ( $\mathrm{P}=0.365$ ) (Table 6).

The survey has revealed that some subdomains of quality of life questionnaire are statistically correlated with each other. General health status subdomain and physical health subdomain $(\mathrm{P}<0.001)$; psychological health subdomain $(\mathrm{P}<0.001)$ and environment subdomain $(\mathrm{P}<0.001)$; physical health subdomain and psychological health subdomain $(\mathrm{P}<0.001)$, environment subdomain $(\mathrm{P}<0.001)$ and social engagement subdomain $(\mathrm{P}<0.001)$ were statistically significantly correlated (Table 7).

\section{Discussion}

Covid-19 which is perceived as a threat to health and global economy resulted in significant regulations such as shut-down of formal education institutions of various levels temporarily, introduction of part-time work, homeoffice work, social isolation and keeping social distance. These interventions had an impact on daily life behaviors of the individuals and have led to panic and anxiety sometimes and an increase in depressive tendencies some other times.

Results of this survey may be assessed in three sections. First, impact of Covid-19 in internet addiction of adolescents, second, impact of Covid-19 in quality of life of adolescents and third and last, correlation between internet addiction and quality of life of adolescents during Covid-19 pandemic. Internet addiction of adolescents during Covid-19 pandemic is found to be high. These results are similar to the study carried out by (Ko et al., 2008) also obtained similar results in their study carried out before the pandemic. Thus, more accurate assessment of internet addiction data obtained in this study is possible only when internet addiction level of the adolescents before the pandemic is determined. 
Black Sea Journal of Health Science

Table 6. Results of the correlation analysis of internet addiction and life quality scores of adolescents participating in the survey

\begin{tabular}{|c|c|c|c|c|c|c|c|}
\hline & & \multirow{2}{*}{$\begin{array}{c}\text { Internet } \\
\text { addiction }\end{array}$} & \multicolumn{5}{|c|}{ Quality of Life } \\
\hline & & & $\begin{array}{l}\text { General } \\
\text { health }\end{array}$ & $\begin{array}{l}\text { Physical } \\
\text { health }\end{array}$ & $\begin{array}{l}\text { Psychological } \\
\text { health }\end{array}$ & Environment & $\begin{array}{c}\text { Social } \\
\text { Interaction }\end{array}$ \\
\hline \multicolumn{2}{|c|}{ Internet addiction } & 1 & & & & & \\
\hline \multirow{5}{*}{$\begin{array}{l}\text { Quality } \\
\text { of Life }\end{array}$} & General health & -0.133 & 1 & & & & \\
\hline & Physical health & -0.006 & $-0.406^{*}$ & 1 & & & \\
\hline & $\begin{array}{l}\text { Psychological } \\
\text { health }\end{array}$ & 0.075 & $-0.727^{*}$ & $0.404 *$ & 1 & & \\
\hline & Environment & 0.008 & $0.361^{*}$ & $0.335^{*}$ & $-0.391 *$ & 1 & \\
\hline & Social Interaction & -0.047 & -0.051 & $0.431^{*}$ & 0.124 & -0.064 & 1 \\
\hline
\end{tabular}

Table 7. Those with significant results after the correlation analysis of internet addiction and life quality scores of adolescents participating in the survey

\begin{tabular}{|c|c|c|c|c|c|c|c|}
\hline & & \multirow{2}{*}{$\begin{array}{l}\text { Internet } \\
\text { addiction }\end{array}$} & \multicolumn{5}{|c|}{ Quality of Life } \\
\hline & & & $\begin{array}{l}\text { General } \\
\text { health }\end{array}$ & $\begin{array}{c}\text { Physical } \\
\text { health }\end{array}$ & $\begin{array}{c}\text { Psychological } \\
\text { health }\end{array}$ & Environment & $\begin{array}{c}\text { Social } \\
\text { Interaction }\end{array}$ \\
\hline \multicolumn{8}{|c|}{ Internet addiction } \\
\hline \multirow{5}{*}{$\begin{array}{l}\text { Quality of } \\
\text { Life }\end{array}$} & General health & & & & & & \\
\hline & Physical health & & -0.406 & & & & \\
\hline & Psychological health & & -0.727 & 0.404 & & & \\
\hline & Environment & & 0.361 & 0.335 & -0.391 & & \\
\hline & Social Interaction & & & 0.431 & & & \\
\hline
\end{tabular}

Because, it's not known whether higher internet addiction rate of the adolescents has occurred during the pandemic or it's a continuing habit dating back before pandemic.

Internet addiction of adolescents doesn't differ according to sex and income level of the families; but there is a difference according to education status of the family. Internet addiction rate is lower among adolescents with parents who are graduate of junior high and university. In the study performed by (Ko et al., 2008) correlation between education level of the family and internet addiction of the adolescents was found also correlated.

Another attribute determined about internet addiction in this study is that adolescents spent more time internet during the pandemic and narrowed their friendship circle. This finding is in line with the results of the studies done by (King et al., 2014). Insomuch that, King and Delfabbro have stated that adolescents addicted to internet are confused about the game world and real world and started to live in a virtual reality. Again, the finding in our study indicating disruption in daily work of adolescents due to internet addiction is similar with the results of the study done by (Duan et al., 2020). In these studies also it's emphasized that internet is in the center of life of the individuals and adolescents have a tendency to neglect routine daily works and spend more time in the internet. When compared with the study of (Dong et al., 2018) it can be assumed that intercultural differences do not have any impact on internet addiction of adolescents.

The major impact of internet addiction is seen on negligence of education by adolescents. During Covid-19 pandemic education is continued as distance education and online education and adolescents failed to attend these programs due to internet addiction. These results are overlapping with the results of the study done by (Dong et al., 2018). Their study have stated that uncertainty occurring after the shutdown of the schools and intensity of the online courses have increased internet addiction of the individuals.

Another impact of Covid-10 on adolescents is seen on quality of life level. Described as a pandemic disease Covid-19 is a secondary of trauma according to the definition of (Volpe et al., 1996) In this kind of events BSJ Health Sci / Ece Ezgi ÖZAYKAN et al. 
normal thought process changes, stress disorder emerges, depression, deviations in behaviors are seen and anxiety prevails in individuals. This definition of (Volpe et al., 1996) and impacts of Covid-19 on adolescents overlaps.

Quality of life of adolescents deteriorated during Covid19. The results on quality of life of adolescents are similar to the results of the studies done by (Zhou et al., 2020; Yeasmin et al., 2020; Patrick et al., 2020; Ezpeleta et al., 2020; Otto et al., 2020). In the study by Otto et al. (2020) quality of life was found to be worse in Germany compared to the epicenter of the pandemic such as China, Spain and Italy. In our study quality of life scores of adolescents were higher than the adolescents in epicenter of the pandemic such as China, Spain and Italy. Thus, Otto et al. (2020) have suggested that worse quality of life could arise from the preventive measures that are taken during the pandemic rather than Covid-19 pandemic itself. In our study complaints of adolescents about lack of cultural, artistic and hobby-like activities support the suggestion of Otto et al. (2020).

In our study it is determined that quality of life of adolescents varies not according to the family income but sex of the participants; in females quality of life scores were higher. These results are similar to the results of study carried out by (Meral and Cavkaytar, 2014) However, in the study done by (Lemfadli et al., 2020) it's argued that there is a positive relationship between income of the family and quality of life of adolescents. The results in our study aren't in concordance with the study of Lemfadli et al. (2020).

Another aspect assessed in our study regarding quality of life is weight gain of adolescents due to alterations in their dietary habits that also leads to sleep disturbances and thus worsening quality of life during pandemic. Zhang et al. (2020), Sun et al. (2020) and Chen et al. (2020) have found similar results in their respective studies. Moreover, Zhang et al. (2020) and Pulvirenti et al, (2020) have concluded in their studies that stress caused by Covid-19 had an impact on quality of life. Findings such as weight gain and sleep disturbances found in our study are in concordance with the findings of other authors.

Another factor having an impact on quality of life of adolescents during Covid-19 pandemic is their relationship with their families. In the end of our study it's observed that family relationships are regressed during Covid-19 pandemic. This result is in line with the study done by Lau et al. (2003). Impact of another pandemic of the recent years, SARS on quality of life of adolescents in Hong Kong was studied by Lau et al. (2003). In this study also it's found that family relationships of the adolescents were regressed.

Another reason underlying worsening quality of life of adolescents during Covid-19 pandemic was interruption in sports, art or cultural activities of adolescents that led to giving up or withdrawal reactions. This giving up or withdrawal reactions have lowered quality of life of

\section{adolescents}

The latest correlation that is assessed in our study is the correlation of quality of life of adolescents and internet addiction during Covid-19 pandemic. In our study no correlation is found between quality of life of adolescents and internet addiction during Covid-19 pandemic. In other words, during the Covid-19 pandemic decrease or increase in internet addiction of adolescents are independent from decreasing or increasing quality of life of adolescents. This result is in concordance with the studies done by Tang et al. (2014) and Fayazi et al. (2017) before the Covid-19 pandemic.

Covid-19 pandemic had an impact on both quality of life of adolescents and their addiction to internet. Wang et al. (2020) have stated that stress caused by Covid-19 pandemic will affect adolescents for a while after the pandemic. Thus, it's important to monitor internet addiction and quality life of adolescents not only during Covid-19 pandemic but also after the pandemic.

We think that the results of this study will contribute to the provision of required psychological support to the adolescents. It will also shed light over improving coping skills of the individuals and decision-making mechanisms. This study is significant in that there is no national study on impact of Covid-19 on adolescents and in existing international studies target population is usually adults. Further studies may deal with psychological, cognitive and physiological impacts of Covid-19 pandemic on adolescents.

\section{Conclusion}

The present study revealed an increase in internet addiction and a decrease in the quality of life in adolescents during the Covid-19 pandemia. Even though mortal effect of pandemic is heavier in old and chronically ill patients, particularly adolescents are among the most affected population from implementation of preventive measures after occurrence of Covid-19 pandemic. Limited studies targeting adolescent population were carried out in epicenter of the pandemic primarily China and also Spain and Italy. To interfere with internet habits of adolescents who are among the most affected population from Covid-19 pandemic in order to improve their quality of life may lead to conflicts. Instead of this kind of interference, further studies considering quality of life of adolescents and targeting to lower internet addiction rates are needed.

\section{Author Contributions}

All of the authors declare that they have all participated in the design, execution, and analysis of the paper, and that they have approved the final version.

\section{Conflict of Interest}

The authors declare that there is no conflict of interest. 


\section{Ethical Approval/Informed Consent}

This study is carried out in accordance with the approval of the University of Health Sciences Hamidiye Clinical Research Ethics Committee dated July 28, 2020 and no 20-91. Adolescents included into the study were informed about the study with a face to face interview and their families were also informed. Written consent of all the participants and their families were taken.

\section{References}

Banerjee D. 2020. The COVID-19 outbreak: Crucial role the psychiatrists can play. Asian J Psychiatry, 50: 102014.

Chen X, Xu Q, Lin H, Zhu J, Chen Y, Zhao Q, Wang N. 2020. Quality of life during the epidemic of COVID-19 and its associated factors among enterprise workers in East China. BMC Pub Health, 21: 1370.

Dong H, Yang F, Lu X, Hao W. 2020. Internet addiction and related psychological factors among children and adolescents in China during the coronavirus disease 2019 (COVID-19) epidemic. Front in Psychiatry, 11: 751.

Dong X, Wang Y, Chen Y, Wang X, Zhu J, Wang N, Fu C. 2018. Poor sleep quality and influencing factors among rural adults in Deqing, China. Sleep and Breath, 22(4): 1213-1220.

Duan L, Shao X, Wang Y, Huang Y, Miao J, Yang X, Zhu G. 2020. An investigation of mental health status of children and adolescents in china during the outbreak of COVID-19. J Affective Disor, 275: 112-118.

Eser E, Fidaner H, Fidaner C, Eser SY, Elbi H, Göker E. 1999. WHOQOL-BREF TR: a suitable instrument for the assessment of quality of life for use in the health care settings in Turkey. Quality of Life Res, 8: 647-647.

Ezpeleta L, Navarro JB, de la Osa N, Trepat E, Penelo E. 2020. Life conditions during COVID-19 lockdown and mental health in Spanish adolescents. Int J Environ Res and Pub Health, 17(19): 7327.

Fayazi M, Hasani J. 2017. Structural relations between brainbehavioral systems, social anxiety, depression and internet addiction: With regard to revised Reinforcement Sensitivity Theory (r-RST). Comp in Human Behav, 72: 441-448.

King DL, Delfabbro PH. 2014. The cognitive psychology of Internet gaming disorder. Clinical Psychology Rev, 34(4): 298-308.

Ko CH, Yen JY, Yen CF, Chen CS, Weng CC, Chen CC. 2008. The association between Internet addiction and problematic alcohol use in adolescents: the problem behavior model. Cyber Psychology \& Behav, 11(5): 571-576.

Kutlu M, Savcı M, Demir Y, Aysan F. 2016. Young internet bağımlılı̆̆ testi kısa formunun türkçe uyarlaması: üniversite öğrencileri ve ergenlerde geçerlilik ve güvenilirlik çalışması. Anadolu Psikiyatri Derg, 17(1): 69-76.

Lau JTF, Yang X, Tsui H, Kim JH. 2003. Monitoring community responses to the SARS epidemic in Hong Kong: from day 10 to day 62. J Epidemiol \& Commun Health, 57(11): 864-870.

Lemfadli Y, Samlani Z, Errami AA, Oubaha S, Krati K. 2020. The impact of the COVID-19 pandemic on quality of life and wellbeing in Morocco, 2020: 2020060287.

Meral BF, Cavkaytar A. 2014. Otizmli çocuk ailelerinin aile yaşam kalitesi algıları. Kastamonu Eğitim Derg, 23(3): 13631380.

Metintaş S, Emrah ATAY. 2019. Dermatolojik hastalarda araştırma yöntemleri. ESTÜDAM Halk Sağlığı Derg, 4: 1-26.

Otto C, Reiss F, Voss C, Wüstner A, Meyrose AK, Hölling H, Ravens-Sieberer U. 2020. Mental health and well-being from childhood to adulthood: design, methods and results of the 11-year follow-up of the BELLA study. European Child \& Adol Psychiatry, 2020: 1-19. DOI: 10.1007/s00787-020-01630-4.

Patrick SW, Henkhaus LE, Zickafoose JS, Lovell K, Halvorson A, Loch S, Davis MM. 2020. Well-being of parents and children during the COVID-19 pandemic: a national survey. Pediatrics, 146(4): e2020016824.

Pawlikowski M, Altstötter-Gleich C, Brand M. 2013. Validation and psychometric properties of a short version of Young's Internet Addiction Test. Comp in Human Behav, 29(3): 12121223.

Pulvirenti F, Cinetto F, Milito C, Bonanni L, Pesce AM, Leodori G, Quinti I. 2020. Health-related quality of life in common variable immunodeficiency Italian patients switched to remote assistance during the COVID-19 pandemic. The J Allergy and Clinical Immun: In Prac, 8(6): 1894-1899.

Sun Y, Li Y, Bao Y, Meng S, Sun Y, Schumann G, Shi J. 2020. Brief report: increased addictive internet and substance use behavior during the COVID-19 pandemic in China. The American J on Addict, 29(4): 268-270.

Suryaman M, Cahyono Y, Muliansyah D, Bustani O, Suryani P, Fahlevi M, Munthe AP. 2020. COVID-19 pandemic and home online learning system: Does it affect the quality of pharmacy school learning. Syst Rev in Pharmacy, 11(8): 524-530.

Tang J, Yu Y, Du Y, Ma Y, Zhang D, Wang J. 2014. Prevalence of internet addiction and its association with stressful life events and psychological symptoms among adolescent internet users. Addictive Behav, 39(3): 744-747.

Volpe J. 1996. Effects of domestic violence on children and adolescents: An overview. American Acad of Experts in Trauma Stress, 1996: 1-4.

Wang YY, Long J, Liu YH, Liu TQ, Billieux J. 2020. Factor structure and measurement invariance of the problematic mobile phone use questionnaire-short version across gender in Chinese adolescents and young adults. BMC Psychiatry, 20(1): 1-9.

WHO. 2021. URL: https://www.who.int/healthtopics/adolescent-health\#tab=tab_1, (accessed date: 20.04.2021).

WHOQoL Group. 1994. The development of the World Health Organization quality of life assessment instrument (the WHOQOL). In Quality of life assessment: International perspectives. Springer, Berlin, Heidelberg, Germany, pp. 4157.

Yeasmin S, Banik R, Hossain S, Hossain MN, Mahumud R, Salma N, Hossain MM. 2020. Impact of COVID-19 pandemic on the mental health of children in Bangladesh: A cross-sectional study. Children and Youth Services Rev, 117: 105277.

Zhang SX, Wang Y, Rauch A, Wei F. 2020. Health, distress and life satisfaction of people in China one month into the COVID19 outbreak. Distress and Life Satisfaction of People in China One Month into the COVID-19 Outbreak (3/12/2020). LANCET, URL: https://papers.ssrn.com/sol3/papers.cfm?abstract_id=3555 216 (access date: 03.03.2021)

Zhang Y, Ma ZF. 2020. Impact of the COVID-19 pandemic on mental health and quality of life among local residents in Liaoning Province, China: A cross-sectional study. Int J Envir Res and Public Health, 17(7): 2381.

Zhou SJ, Zhang LG, Wang LL, Guo ZC, Wang JQ, Chen JC, Chen JX. 2020. Prevalence and socio-demographic correlates of psychological health problems in Chinese adolescents during the outbreak of COVID-19. European Child \& Adol Psychiatry, 29(6): 749-758. 